\begin{tabular}{l|c|c}
\hline $\begin{array}{l}\text { ISSN: 0001-5113 } \\
\text { AADRAY }\end{array}$ & ACTA ADRIAT., & ORIGINAL SCIENTIFIC PAPER \\
\hline \hline
\end{tabular}

\title{
New records of the alien polychaete worm Chaetozone corona (Polychaeta: Cirratulidae) in the Adriatic Sea
}

\author{
Laura GROSSI ${ }^{1}$, Fabio BERTASI ${ }^{*}$ and Benedetta TRABUCCO ${ }^{1}$ \\ ${ }^{1}$ ISPRA, Institute for Environmental Protection and Research, Via di Castel Romano 100, \\ 00128 Rome, Italy
}

Corresponding author, e-mail: fabio.bertasi@gmail.com

Several specimens of the alien polychaete Chaetozone corona were encountered at sites along the Italian coasts of the Adriatic Sea between 2006 and 2015, indicating its successful establishment in the area. Morphological variability between specimens from the North Adriatic and the South Adriatic was detected. Methyl Green staining patterns revealed further minor differences suggesting the presence of two slightly different populations. Chaetozone corona does not appear to be invasive in natural conditions, but it appears more abundant in polluted port sediments, what may represent the main source of introduction.

Key words: Chaetozone corona, alien species, Adriatic Sea, Italy

\section{INTRODUCTION}

New records of the polychaete Chaetozone corona Berkeley \& Berkeley, 1941 are rapidly adding up across European coasts, providing new evidences that seem to confirm its nature as an alien species both for the North-East Atlantic (LE GARREC et al., 2017) and Mediterranean waters (MUNARI et al., 2017; ZENETOS et al., 2017). This polychaete was originally described by BERKELEY \& BERKELEY (1941) on the coast of southern California. Since then, C. corona was reported in western Mexico (BLAKE, 1996), on the Pacific coast of Costa Rica (DEAN et al., 2007), on the western Atlantic coast of Brazil (OMENA et al., 2004), and in the coastal waters of the east coast of Florida (BLAKE unpublished, cit. in LE GARREC et al., 2017). First records of $C$. corona in the Mediterranean Sea were from the
Turkish Aegean and Levantine coasts [ÇINAR \& ERGEN, 2007 (collection date: 1980-2007); ÇINAR, 2009 (collection date: 2005); ÇINAR et al. 2012a, b (collection date: 2009); ÇINAR \& DAGLI, 2013 (collection date: 2011)], Sea of Marmara (ÇINAR et al., 2011a; collection date: 2006); the Greek Aegean and Ionian Sea coasts (SIMBOURA, 1996 (collection date: 1982); SIMBOURA et al., 2010). More recently, C. corona was found on the North Atlantic coast of France, where specimens were first sampled in 1996 (LE GARREC et al., 2017). Recent records by MUNARI et al. (2017) on the Central Adriatic Sea and on Tyrrhenian coasts (collection date: 2014 - 2016) further extended the geographic range of $C$. corona suggesting a possible expansion on the western Mediterranean basin.

The genus Chaetozone currently includes 55 valid species worldwide, with eight species reported from the Mediterranean Sea (BELLAN, 


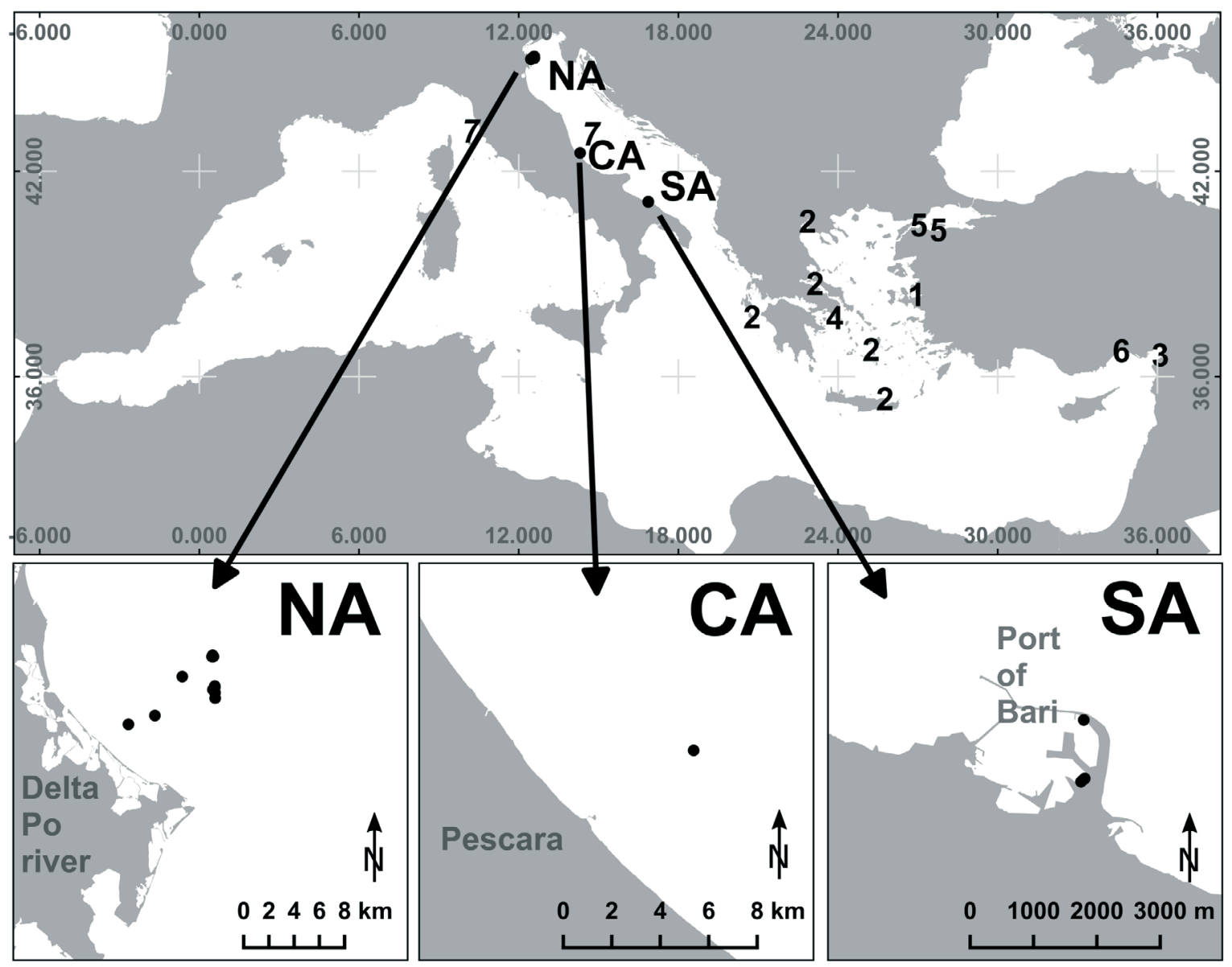

Fig. 1. Map of the new records of Chaetozone corona on the North (NA), central (CA) and South (SA) Adriatic Sea coast, Italy, and its known distribution in the Mediterranean Sea. Black dots are sampling stations. Numbers are references to previous records: 1. Aegean Sea, Izmir Bay (Ildiri, Gerence, Nemrut bay) (ÇINAR \& ERGEN, 2007; ÇINAR et al., 2012b); 2. Zakynthos island, Evvoikos Gulf, Thermaikos Gulf, Kyklades, Crete (SIMBOURA, 1996); 3. Levantine Sea, Iskenderun Bay (ÇINAR, 2009); 4. Elefsis bay, Saronikos gulf (SIMBOURA et al., 2010); 5. Sea of Marmara, Gelibolu and Erdek (ÇINAR et al., 2011a); 6. Mersin Bay (ÇINAR et al., 2012a); ); 7. Adriatic Sea and Tyrrhenian Sea (MUNARI et al., 2017)

2017). Five of those species are present in the Adriatic basin (MIKAC, 2015): C. caputesocis de Saint-Joseph, 1894, C. carpenteri McIntosh, 1911, Chaetozone corona Berkeley \& Berkeley, 1941, C. gibber Woodham \& Chambers, 1994 and C. setosa Malmgren, 1867.

In the benthic samples collected along the western Adriatic Sea coast during several monitoring projects since 2006, specimens of unidentified species of Chaetozone, or doubtfully C. setosa, have been regularly found. A re-examination of many specimens of the genus Chaetozone revealed that they were C. corona. In this study, the new records of C. corona are being given for the Adriatic Sea.

\section{MATERIALS AND METHODS}

The samples were collected during various benthic surveys carried out by ISPRA (Institute for Environmental Protection and Research) on several sites along the western Adriatic Sea coast (Fig. 1). Sampling site NA (depth: 3-30 m) was located in the North Adriatic Sea, in front of the Po river delta; sampling site CA (depth: 20 and $70 \mathrm{~m}$ ) on the central Adriatic coast off Pescara; sampling area SA (depth: 9-14 m) inside the port of Bari (SA) in the South Adriatic Sea (Fig. 1). Sediments were collected with a Van Veen grab $\left(0.1 \mathrm{~m}^{-2}\right)$ both for macrofauna and sediment grain-size analyses, taking two repli- 
Table 1. Characterisation of sampling sites and number of specimens of Chaetozone corona collected in this study

\begin{tabular}{|c|c|c|c|c|c|c|}
\hline Sampling time & Site & $\begin{array}{l}\text { Latitude } \\
\text { (WGS84) }\end{array}$ & $\begin{array}{l}\text { Longitude } \\
\text { (WGS84) }\end{array}$ & $\begin{array}{l}\text { Depth } \\
\text { (m) }\end{array}$ & $\begin{array}{l}\text { Sediment } \\
\text { description }\end{array}$ & $\begin{array}{l}\text { Chaetozone } \\
\text { corona } \text { n. of } \\
\text { specimens }\end{array}$ \\
\hline 17 June 2006 & NA.1 & $45^{\circ} 05^{\prime} 27.85^{\prime \prime}$ & $12^{\circ} 34^{\prime} 53.47^{\prime \prime}$ & 28 & fine sand & 2 \\
\hline 17 June 2006 & NA.2 & $45^{\circ} 06^{\prime} 17.71^{\prime \prime}$ & $12^{\circ} 32^{\prime} 07.69^{\prime \prime}$ & 27 & fine sand & 2 \\
\hline 02 October 2008 & NA.3 & $45^{\circ} 05^{\prime} 16.15^{\prime \prime}$ & $12^{\circ} 35^{\prime} 04.85^{\prime \prime}$ & 28 & fine sand & 1 \\
\hline 18 September 2010 & NA.4 & $45^{\circ} 05^{\prime} 36.82^{\prime \prime}$ & $12^{\circ} 35^{\prime} 03.98^{\prime \prime}$ & 28 & fine sand & 2 \\
\hline 18 September 2010 & NA.5 & $45^{\circ} 05^{\prime} 20.47^{\prime}$ & $12^{\circ} 34^{\prime} 39.61^{\prime \prime}$ & 28 & fine sand & 1 \\
\hline 18 September 2010 & NA.6 & $45^{\circ} 03^{\prime} 15.05^{\prime}$ & $12^{\circ} 27^{\prime} 16.38^{\prime \prime}$ & 18 & muddy sand & 1 \\
\hline 16 July 2012 & NA.7 & $45^{\circ} 03^{\prime} 48.71^{\prime}$ & $12^{\circ} 29^{\prime} 39.59^{\prime \prime}$ & 26 & fine sand & 2 \\
\hline 06 May 2014 & NA.8 & $45^{\circ} 07^{\prime} 34.21^{\prime \prime}$ & $12^{\circ} 34^{\prime} 56.24^{\prime \prime}$ & 27 & fine sand & 2 \\
\hline 06 May 2014 & NA.3 & $45^{\circ} 05^{\prime} 16.15^{\prime \prime}$ & $12^{\circ} 35^{\prime} 04.85^{\prime \prime}$ & 28 & fine sand & 3 \\
\hline 09 November 2014 & NA.10 & $45^{\circ} 07^{\prime} 38.96^{\prime \prime}$ & $12^{\circ} 34^{\prime} 52.07^{\prime \prime}$ & 27 & fine sand & 2 \\
\hline 09 November 2014 & NA.11 & $45^{\circ} 05^{\prime} 41.64^{\prime \prime}$ & $12^{\circ} 35^{\prime} 03.77^{\prime \prime}$ & 28 & fine sand & 5 \\
\hline 23 July 2015 & NA.12 & $45^{\circ} 07^{\prime} 34.03^{\prime \prime}$ & $12^{\circ} 34^{\prime} 48.29^{\prime \prime}$ & 27 & fine sand & 3 \\
\hline 23 July 2015 & NA.13 & $45^{\circ} 04^{\prime} 55.09^{\prime \prime}$ & $12^{\circ} 35^{\prime} 05.75^{\prime \prime}$ & 28 & fine sand & 3 \\
\hline 06 October 2015 & NA.10 & $45^{\circ} 07^{\prime} 38.96^{\prime \prime}$ & $12^{\circ} 34^{\prime} 52.07^{\prime \prime}$ & 27 & fine sand & 3 \\
\hline 06 October 2015 & NA.13 & $45^{\circ} 04^{\prime} 55.09^{\prime \prime}$ & $12^{\circ} 35^{\prime} 05.75^{\prime \prime}$ & 28 & fine sand & 6 \\
\hline 25 July 2006 & CA.1 & $42^{\circ} 30^{\prime} 28.80^{\prime \prime}$ & $14^{\circ} 18^{\prime} 22.79^{\prime \prime}$ & 25 & sandy silt & 2 \\
\hline 27 May 2014 & SA.1 & $41^{\circ} 08^{\prime} 32.14^{\prime \prime}$ & $16^{\circ} 52^{\prime} 03.83^{\prime \prime}$ & 14 & muddy sand, with vegetal debris & 1 \\
\hline 27 May 2014 & SA. 2 & $41^{\circ} 08^{\prime} 02.33^{\prime \prime}$ & $16^{\circ} 52^{\prime} 05.88^{\prime \prime}$ & 7 & muddy sand, with vegetal debris & 14 \\
\hline 27 May 2014 & SA.3 & $41^{\circ} 08^{\prime} 00.60^{\prime \prime}$ & $16^{\circ} 52^{\prime} 03.43^{\prime \prime}$ & 7 & muddy sand, with vegetal debris & 26 \\
\hline 11 November 2014 & SA.4 & $41^{\circ} 08^{\prime} 01.54^{\prime \prime}$ & $16^{\circ} 52^{\prime} 04.73^{\prime \prime}$ & 7 & muddy sand with coarse shell debris & 4 \\
\hline
\end{tabular}

cates in each site for the macrofauna and one for the sediment. The faunal samples were then processed through a $1 \mathrm{~mm}$ mesh-size sieve and the retained fraction was preserved in $4 \%$ formaldehyde buffered with $\mathrm{CaCO}_{3}$ and stored in plastic jars. All benthic organisms were counted and identified in the laboratory under Leica S8APO stereomicroscope $(80 \mathrm{X})$ at the lowest possible taxonomic level (i.e. species) and preserved in $70 \%$ ethanol aqueous solution for longterm storage. Sediment grain-size was analysed according to DEAN (1974). Re-examination of Chaetozone corona specimens was carried out by staining specimens with Shirlastain A to aid the observation of external characters, and with Methyl Green to verify colour patterns provided in literature (DEAN \& BLAKE, 2007; LE GARREC et al., 2017). Specimens were dissected under stereomicroscopes and under Leica DM2500 optical microscope (400X) to observe chaetal structures. A Panasonic Lumix DMC-LX3 mounted on compound and stereomicroscope was used for digital photographs and the software Image J 1.46 was used for morphometric measures. The specimens of $C$. corona from the Adriatic Sea are deposited in the Laboratory of Benthos Ecology collection, ISPRA (Rome, Italy). Three comparative specimens from the North-East Atlantic coast of France were kindly provided by Dr. Vincent LE GARREC, Observatoire - UMS 3113, Institut Universitaire Européen de la Mer. 


\section{RESULTS AND DISCUSSION}

\section{SYSTEMATICS}

Class POLYCHAETA Grube, 1850

Family CIRRATULIDAE Ryckholt, 1851

Genus Chaetozone Malmgren, 1867

Type species: Chaetozone setosa Malmgren, 1867

Chaetozone corona: Hartman, 1960, p. 125; Hartman, 1961, pp. 109-110; Blake, 1996, pp. 285-287, Fig. 8.6; Çinar \& Ergen, 2007, pp. 341-345, Figs. 2-4; Dean \& Blake, 2007, pp. 46-47, Fig. 3; Çinar, 2009, pp. 2304-2305; Simboura et al., 2010, p.342, Fig. 1A-B; Blake, 2015, Table 2; Le Garrec et al., 2017, p. 3, Fig. 2; Munari et al, 2017, p. 544, Fig.2.

Material examined. North Adriatic Sea, off Po river delta (Italy): 17.06.2006, st. NA. $1,45^{\circ} 05^{\prime} 27.85^{\prime} \mathrm{N} 12^{\circ} 34^{\prime} 53.47^{\prime}$ E, depth $28 \mathrm{~m}$, fine sand, 2 specimens, ISPRA.48; 17.06.2006, st. NA.2, $45^{\circ} 06^{\prime} 17.71^{\prime \prime} \mathrm{N} 12^{\circ} 32^{\prime} 07.69^{\prime \prime} \mathrm{E}, 27 \mathrm{~m}$, fine sand, 2 specimens, ISPRA.49; 02.10.2008, st. NA.3, $45^{\circ} 05^{\prime} 16.15^{\prime} \mathrm{N} 12^{\circ} 35^{\prime} 04.85^{\prime} \mathrm{E}, 28 \mathrm{~m}$, fine sand, 1 specimen, ISPRA.50; 18.09.2010, st.

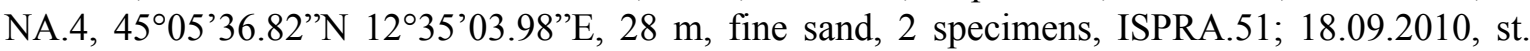

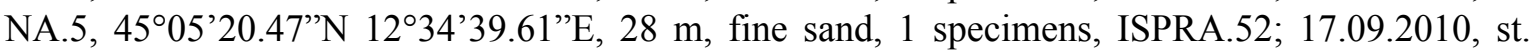
NA.6, $45^{\circ} 03^{\prime} 15.05^{\prime} \mathrm{N} 12^{\circ} 27^{\prime} 16.38^{\prime \prime} \mathrm{E}, 18 \mathrm{~m}$, muddy sand, 1 specimen, ISPRA.53; 16.07.2012, st. NA.7, $45^{\circ} 03^{\prime} 48.71^{\prime \prime} \mathrm{N} 12^{\circ} 29^{\prime} 39.59^{\prime}$ 'E, $26 \mathrm{~m}$, fine sand, 2 specimens, ISPRA.54; 06.05.2014, st. NA.8, 45 $07^{\circ} 34.21^{\prime \prime} \mathrm{N} 12^{\circ} 34^{\prime} 56.24^{\prime \prime}$, $27 \mathrm{~m}$, fine sand, 2 specimens, ISPRA.55; 06.05.2014, st. NA. $3,45^{\circ} 05^{\prime} 16.15^{\prime} \mathrm{N} 12^{\circ} 35^{\prime} 04.85^{\prime} \mathrm{E}, 28 \mathrm{~m}$, fine sand, 2 specimens, ISPRA.56; 09.11.2014, st.

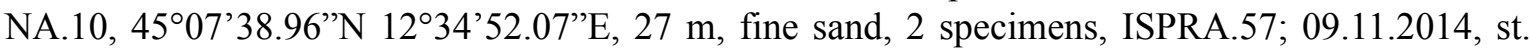
NA.11, 45 $05^{\circ} 41.64^{\prime} \mathrm{N} 12^{\circ} 35^{\prime} 03.77^{\prime}$ 'E, $28 \mathrm{~m}$, fine sand, 4 specimens, ISPRA.58; 23.07.2015, st.

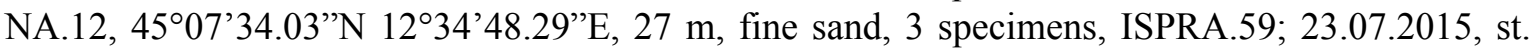
NA.13, 45 04 '55.09”'N 12 ${ }^{\circ} 35^{\prime} 05.75^{\prime}$ 'E, $28 \mathrm{~m}$, fine sand, 2 specimens, ISPRA.60; 06.10.2015, st. NA.10, 45 $07^{\circ} 38.96^{\prime} \mathrm{N} 12^{\circ} 34^{\prime} 52.07^{\prime} \mathrm{E}, 27 \mathrm{~m}$, fine sand, 3 specimens, ISPRA.61; 06.10.2015, st. NA.13, 45 $04^{\prime} 55.09^{\prime \prime} \mathrm{N} 12^{\circ} 35^{\prime} 05.75^{\prime}$ 'E, $28 \mathrm{~m}$, fine sand, 2 specimens, ISPRA.62. Central Adriatic Sea, off Pescara (Italy): 25.07.2006, CA.1, 42 ${ }^{\circ} 30^{\prime} 28.80^{\prime \prime N} 14^{\circ} 18^{\prime} 22.79^{\prime \prime} \mathrm{E}, 25 \mathrm{~m}$, sandy silt, 2 specimens, ISPRA.47. South Adriatic Sea, port of Bari (Italy): 27.05.2014, station SA.1, 41 ${ }^{\circ} 08^{\prime} 32.14$ 'N $16^{\circ} 52^{\prime} 03.83^{\prime}$ 'E, $14 \mathrm{~m}$, muddy sand with vegetal debris, 1 specimen, ISPRA.43; 27.05.2014, st. SA.2, $41^{\circ} 08^{\prime} 02.33^{\prime}$ 'N $16^{\circ} 52^{\prime} 05.88^{\prime \prime} \mathrm{E}, 7 \mathrm{~m}$, muddy sand with vegetal debris, 6 specimens, ISPRA.44; 27.05.2014, st. SA.3, $41^{\circ} 08^{\prime} 00.60^{\prime \prime} \mathrm{N} 16^{\circ} 52^{\prime} 03.43^{\prime \prime} \mathrm{E}, 7 \mathrm{~m}$, muddy sand with vegetal debris, 2

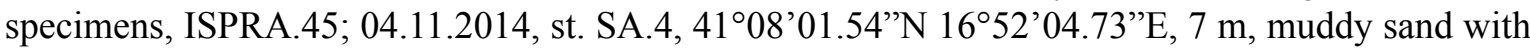
coarse shell debris, 3 specimens, ISPRA.46.

Out of 44 examined specimens of Chaetozone corona, 26 were complete specimens.

\section{Additional material examined}

Molène archipelago (France): 03/2014, St.3, 48²3'12.48'N 451'15.36”'E, 12 m, maerl bed, 1 specimen, MMO3. Bay of Camaret (France): 03/2015, 48¹7’35.70”'N 4³4'47.82”'E, 14 m, maerl bed, 2 specimens, MCM1.

\section{Description}

Largest complete specimen from NA, 25.8 mm long (ISPRA.62), $1.8 \mathrm{~mm}$ wide, with 56 chaetigers. Body cylindrical in anterior half, dorsoventrally flattened in posterior half. Pos- terior-most chaetigers with an accordion-like appearance (Fig. 2A, B). A shallow dorsal furrow, often best seen about between chaetigers 10 and 20 (Fig. 2A, B), and shallow ventral furrow, present throughout the body. Colour in ethanol creamy white, iridescent, with black spots on lateral and ventral sides of peristomium and laterally or ventrolaterally on first chaetigers. Several specimens from NA with black spots faded or absent. Prostomium conical, pointed; 2 black eyes (Fig. 2A, B, C); peristomium with three annulations, second with a dorsal rounded crest, 
overlapping third annulation and extending to chaetiger 1; dorsal tentacles arising between second and third peristomial annulations (Fig. 2C). First pair of branchiae on posterior margin of third peristomial annulation, posterolateral to dorsal tentacles (Fig. 2C). Branchiae after dorsal-most notochaetae on the posterior margin of each chaetiger. Notochaetae thin capillaries, longer than body width, arranged in a single row, increasing in length up to about chaetiger 35 ; notopodial spines first appearing on chaetiger 1-8 in specimens from NA, spines present only after chaetiger 6-9 in specimens from SA. Neuropodial capillaries and spines first present from chaetiger 1 (Fig. 2D). Spines forming partial cinctures in posterior segments alternated with thin capillaries (Fig. 2E), up to 12 spines on a side, maximum 6 spines on neuropodia. Anteriorly, spines slightly curved, bluntly pointed, pale yellow or almost transparent; thicker in posterior chaetigers, slightly curved, bluntly pointed, dark yellow. Pygidium with simple ventral lobe, anus dorsal.

\section{Methyl Green staining}

Prostomium and peristomium entirely stained blue in specimens from NA and CA (Fig. 2B), prostomium tip light green or unstained in specimens from SA (Fig. 2C); light green all over the rest of body (Fig. 2B).

\section{Remarks}

The presence of notopodial spines appearing from the first chaetiger was observed in about $40 \%$ of our specimens from NA, but in none of the specimens from SA. This feature was recently noted also in some specimens from the Mediterranean Sea (ÇINAR \& ERGEN, 2007) and from North-East Atlantic (LE GARREC et al., 2017), but was not found in specimens from the Central Adriatic Sea by MUNARI et al., (2017). When notopodial spines are present on the first chaetiger, they usually appear also on all subsequent notopodia. Specimens from SA differ from those found at NA and CA by smaller average body size, absence of spines in first notopodia, marked black dots on peristomium and first chaetigers (often faded in several specimens
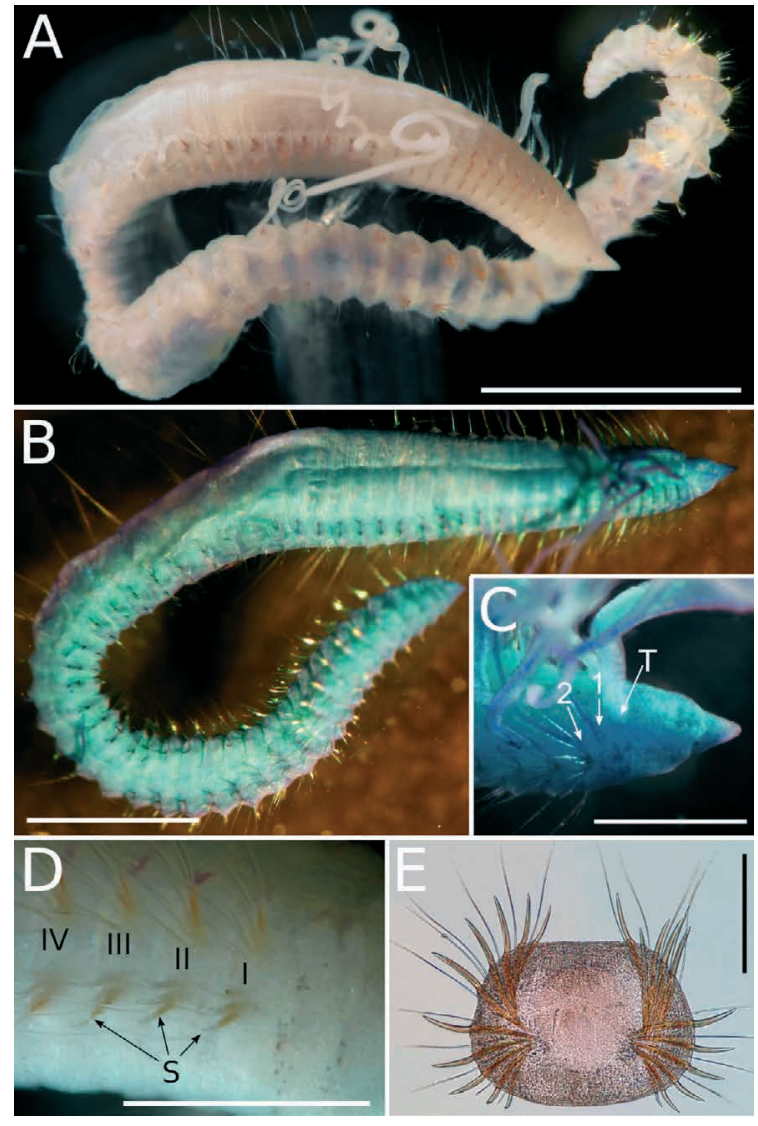

Fig. 2. Chaetozone corona Berkeley \& Berkeley, 1941: (A) specimen from the port of Bari (South Adriatic Sea) (ISPRA.43); (B) specimen from off Po river delta (North Adriatic Sea), stained with Methyl Green (ISPRA.49); (C) Methyl Green staining in a specimen from the port of Bari (ISPRA.45), anterior end; (D) posterior chaetiger, cross section (ISPRA.44); (E) first four chaetigers, lateral view (ISPRA.43). I - IV, chaetiger number from front to back; $S$, neuropodial spines; $T$, insertion of tentacles; 1 , insertion of first pair of branchiae; 2, insertion of second pair of branchiae. Scale bars: A, $2 \mathrm{~mm} ; B, 2 \mathrm{~mm} ; C, 0.3 \mathrm{~mm}$; $D, 0.5 \mathrm{~mm} ; E, 0.3 \mathrm{~mm}$

from NA and CA, as noted also by MUNARI et al., 2017) and prostomium tip not staining with Methyl Green (dark blue in specimens from NA and CA). Methyl Green staining pattern appears to be identical between specimens from SA and those from southern California (BLAKE, 1994), Pacific Costa Rica (DEAN \& BLAKE, 2007) and France (LE GARREC et al., 2017). No descriptions of this feature are provided for specimens from the Mediterranean area. Therefore, is not clear if the specimens from NA may represent the 
only exception to the common Methyl Green staining pattern for C. corona. The examination of material from the Molène arcipelago and the Bay of Camaret (France) revealed some minor differences with the specimens from NA area. In particular, animals from North Adriatic had notopodial spines in the posterior chaetigers more robust than in the specimens from France. Conversely, no substantial differences were found between the specimens from France and SA. Our observations seem to indicate a closer resemblance between the specimens of $C$. corona from North-East Atlantic and those from the port of Bari. The morphological differences found between NA and SA specimens may be related to the different size of the specimens, but may also suggest the presence of two slightly different populations in those geographic areas. Besides this variability, which still lies between the species range, all specimens both from North and South Adriatic Sea agree with the descriptions of C. corona from East Pacific (BERKELEY \& BERKELEY, 1941; BLAKE, 1996; DEAN et al., 2007), West and East Atlantic (OMENA et al., 20 04; LE GARREC et al., 2017) and Mediterranean Sea (ÇINAR \& ERGEN, 2007).

In our samples from NA, C. corona was seldom found together with $C$. carpenteri (see also MUNARI et al., 2017) The two species are similar for overall body shape, presence of notopodial spines from chaetiger 6-9 and partial cinctures in posterior segments accompanied by thin capillaries. Methyl Green pattern is similar between the two species and does not help in distinguish them. However, C. corona can be readily distinguished from $C$. carpenteri by the presence of spines in neuropodia from the first chaetiger, and by the first pair of branchiae appearing on the posterior margin of the last peristomial annulation on first chaetiger in $C$. carpenteri (CHAMBERS et al., 2011). In the past, both species were probably confused with $C$. setosa in the Mediterranean Sea (ÇINAR \& ERGEN, 2007; CHAMBERS et al., 2011), therefore most records for $C$. setosa in the Adriatic Sea are doubtful and could be referred to C. corona or C. carpenteri, and probably also to another undescribed species.

\section{Ecology}

In the Pacific Ocean, Chaetozone corona was sampled from the intertidal zone to 119 $\mathrm{m}$ depth within heterogeneous habitats ranging from coarse sand to either silt or mud, or mixed sediments with shell debris, both in maerl and seagrass beds (BERKELEY \& BERKELEY, 1941; HARTMAN, 1960, 1961; BLAKE, 1996, 2015). On the Brazilian Atlantic coast, OMENA \& CREED (2004) found $C$. corona in seagrass beds, inhabiting both muddy and fine sands, between 0.5 and 3 $m$ depths, while on North-East Atlantic coast of France, LE GARREC et al. (2017) found it in maerl bed, sandy gravel, gravelly sand and sandy mud, within 6 and $49 \mathrm{~m}$ depth, with the highest abundances observed in gravelly sands. In the eastern Mediterranean Sea C.corona has been reported inhabiting coastal areas in several substrates, within a depth range of 2.5 to $100 \mathrm{~m}$. SIMBOURA (1996) found the species on several Greek coasts, in sandy, muddy or mixed sediments at a wide depth range in disturbed and undisturbed sites. In the Levantine Sea, Iskenderun Bay, the species was collected at a depth of 72 and $100 \mathrm{~m}$, in mud (ÇINAR, 2009). In the Sea of Marmara, specimens were collected from 22 to $66 \mathrm{~m}$, in sandy mud, mud and muddy sand sediments (ÇINAR et al., 2011a). C. corona was found also in the Aegean Sea, on the Turkish coast, from 2.5 to $50 \mathrm{~m}$ depth, in mud, sand, sandy mud with shells fragment and Posidonia oceanica (Linnaeus) Delile, 1813 (ÇINAR \& ERGEN, 2007; ÇINAR et al., 2012b) and on the Greek coast, in polluted and semi-polluted areas of Elefsis Bay and the Saronikos Gulf on sandy mud and muddy sand between 20 and $90 \mathrm{~m}$ depth (SIMBOURA et al., 2010). Recent records by MUNARI et al. (2017) were from a depth range from 19 to $100 \mathrm{~m}$, both on silty sand and on clay-silt mixed sediments in the Central Adriatic Sea, and from $20 \mathrm{~m}$ depth, on rocks, in the Tyrrhenian Sea.

In this study, the specimens were collected at 7-14 $\mathrm{m}$ depth, from sheltered and polluted sediments with fine vegetal debris (Posidonia oceanica) mixed with coarse shell debris (SA, port of Bari), at $25 \mathrm{~m}$ depth on sandy silt (CA), and at a depth of 19-30 m, mostly on fine sands (NA). Among all the investigated sites, the spe- 


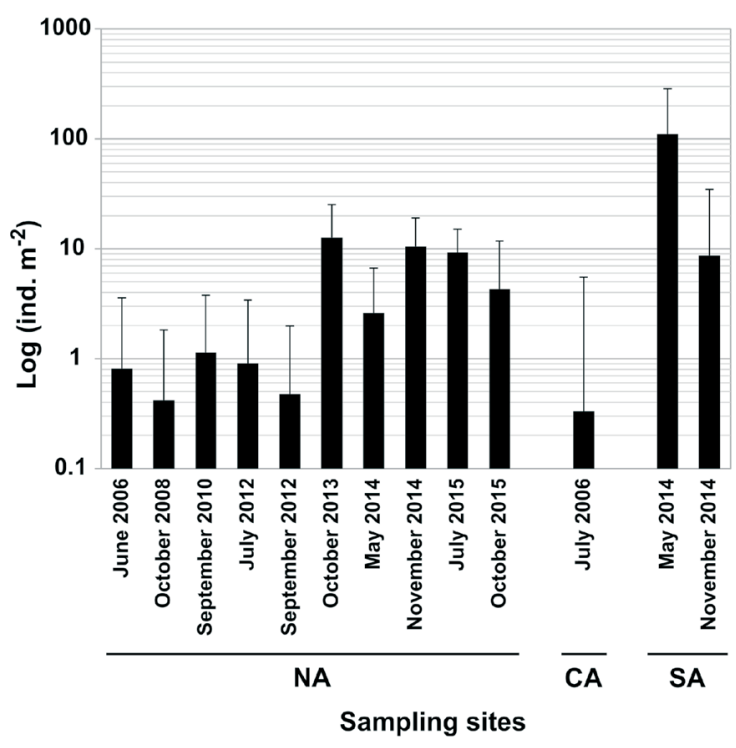

Fig. 3. Log scale of average densities (ind. $\mathrm{m}-2 \pm$ s.d.) of Chaetozone corona recorded in the three areas (NA, CA. SA) at different sampling times. NA $=$ North Adriatic; $\mathrm{CA}=$ Central Adriatic; $\mathrm{SA}=$ South Adriatic.

cies was found with a higher frequency (about $60 \%$ of samples) in the North Adriatic and in the port of Bari ( $40 \%$ of samples). The highest densities were reached in two heavily polluted sites in the port of Bari ( $\max 507$ ind. $\mathrm{m}^{-2}$ ), while in the North Adriatic area values never exceed 30 ind. $\mathrm{m}^{-2}$ (Fig. 3). In North Adriatic, the reexamination of samples from several monitoring campaigns allowed us to estimate the maximum density for the population of $C$. corona through time (Fig. 3). Records from NA seem to indicate an increase in time for the values of the average densities registered for this species, and also confirm its establishment in this area (Fig. 3). Notwithstanding the constant observations from 2006 in North and Central Adriatic soft bottom environments $C$. corona does not exhibit the characters of an invasive species, as pointed out also by MUNARI et al. (2017). Observations by MUNARI et al. (2017) seem to confirm that also in the Central Adriatic Sea abundances have increased from 2006 onward. The high abundances found in the polluted Bari port area seem to indicate that $C$. corona is more prone to show opportunistic traits where environmental conditions are favourable to bio-invasions, par- ticularly via ballast waters (SIMBOURA et al., 2010; ÇINAR et al., 2011b; ÇINAR, 2013).

\section{Distribution}

This species was known from the east Pacific, West and North-East Atlantic; in the Mediterranean, it is reported from Aegean Sea, Levantine Sea, Sea of Marmara and Ionian Sea, Adriatic Sea and North Tyrrhenian Sea. Herein new records for North and South Adriatic Sea.

\section{CONCLUSIONS}

According to our data, Chaetozone corona is an alien species well established along the western Adriatic coast, as proved by multi-annual records, especially on the northern areas. At the moment, the lack of older preserved material in our reference material does not allow to ascertain the presence of $C$. corona in the Adriatic waters before June 2006. However, the presence of particularly high densities of $C$. corona in a port area, confirms that ballast waters represent the most probable way of introduction and spread across the Mediterranean Sea for this species.

\section{ACKNOWLEDGEMENTS}

Specimens collected within the framework of several monitoring projects carried out by ISPRA thanks to management and coordination of Dr. Claudia VIRNO LAMBERTI, Dr. Erika MAGALETTI and Dr. Massimo GABELLINI. Authors would like to thank all Researchers of ISPRA Benthos Ecology Laboratory for helping in fieldwork and in the laboratory sorting activities. We are very grateful to Dr. Vincent LE GARREC, from Observatoire - UMS 3113, Institut Universitaire Européen de la Mer, who sent us the material of $C$. corona from the North-East Atlantic coast of France. We would also like to thank two anonymous referees for valuable suggestions and corrections to improve the manuscript. 


\section{REFERENCES}

BELlaN, G. 2017. Chaetozone Malmgren, 1867, In: G. Read, \& K. Fauchald, (Editors). World Polychaeta Database. Accessed through: World Register of Marine Species.

BERKELEY, E. \& C. BERKELEY. 1941. On a collection of Polychaeta from Southern California. Bull. South. Calif. Acad. Sci., 40: 16-60.

BLAKE, J.A. 2015. New species of Chaetozone and Tharyx (Polychaeta: Cirratulidae) from the Alaskan and Canadian Arctic and the Northeastern Pacific, including a description of the lectotype of Chaetozone setosa Malmgren from Spitsbergen in the Norwegian Arctic. Zootaxa, 3919: 501-552. doi:10.11646/zootaxa.3919.3.5

BLAKE, J.A. 1996. Family Cirratulidae Ryckholdt, 1851. Including a revision of the genera and species from the Eastern North Pacific., In: J.A. Blake, B. Hilbig, P.H. Scott (Editors.). Taxonomic Atlas of the Benthic Fauna of the Santa Maria Basin and the Western Santa Barbara Channel. Volume 6 - The Annelida Part 3. Chapter 8. Polychaeta: Orbiniidae to Cossuridae. Santa Barbara Museum of Natural History, Santa Barbara, CA, Channel, pp. 263-384.

CHAMBERS, S., P. LANERA \& B. MIKAC. 2011. Chaetozone carpenteri McIntosh , 1911 from the Mediterranean Sea and records of other bi-tentaculate Cirratulids. Ital. J. Zool., 78: 41-48. doi:10.1080/11250003.2011.58 0565

ÇINAR, M.E. 2009. Alien polychaete species (Annelida: Polychaeta) on the southern coast of Turkey (Levantine Sea, eastern Mediterranean), with 13 new records for the Mediterranean Sea. J. Nat. Hist., 43: 2283-2328. doi:10.1080/00222930903094654.

ÇINAR, M.E. 2013. Alien polychaete species worldwide: current status and their impacts. J. Mar. Biolog. Assoc. U.K., 93: 1257-1278. ÇINAR, M.E. \& Z. ERGEN. 2007. The presence of Chaetozone corona (Polychaeta: Cirratulidae) in the Mediterranean Sea: an alien or a native species? Cah. Biol. Mar., 48: 339-346.
ÇINAR, M.E., E. DAGLI \& S. AÇIK. 2011a. Annelids (Polychaeta and Oligochaeta) from the Sea of Marmara, with descriptions of five new species. J. Nat. Hist., 45: 2105-2143.

ÇINAR, M.E., M. BILECENOGLU, B. ÖZTÜRK, T. KATAĞAN, M.B. YOKEŞ, V. AYSEL, E. DAGLI, S. AÇIK, T. ÖZCAN \& H. ERDOĞAN. 2011b. An updated review of alien species on the coasts of Turkey. Mediterr. Mar. Sci., 12: 257-315.

ÇINAR, M.E., T. KATAGAN, B. ÖZTÜRK, K. BAKIR, E. DAGLI, S. AÇIK, A. DOGAN, B. BITLIS, K. BAKIR \& A. DOGAN. 2012a. Spatio-temporal distributions of zoobenthos in Mersin Bay (Levantine Sea, eastern Mediterranean) and the importance of alien species in benthic communities. Mar. Biol. Res., 8: 954-968. doi:10.1017/S0025315412000264

ÇINAR, M.E., T. KATAGAN , B. ÖZTÜRK , K. BAKIR , E. DAGLI, S. AÇIK, A. DOGAN \& B. BITLIS. 2012b. Spatio-temporal Distributions of zoobenthos in soft substratum of Izmir Bay (Aegean Sea, eastern Mediterranean), with special emphasis on alien species and ecological quality status. J. Mar. Biolog. Assoc. U.K., 92: 1457-1477.

DEAN, H.K. \& J.A. BLAKE. 2007. Chaetozone and Caulleriella (Polychaeta: Cirratulidae) from the Pacific Coast of Costa Rica, with description of eight new species. Zootaxa, 1451: 41-68.

DEAN, W.E. 1974. Determination of carbonate and organic matter in calcareous sediments and sedimentary rocks by loss on ignition: comparison with other methods. J. Sediment. Res., 44: 242-248. doi:10.1306/74D729D22B21-11D7-8648000102C1865D

HARTMAN, O. 1961. Polychaetous annelids from California. Allan Hancock Pacific Exped., 25: 1-226.

HARTMAN, O. 1960. Systematic account of some marine invertebrate animals from the deep basins off Southern California. Allan Hancock Pacific Exped., 22: 69-215.

LE GARREC, V., J. GRALL, C. CHEVALIER, B. GUYONNET, J. JOURDE, N. LAVESQUE, P. BONIFÁCIO \& J.A. BLAKE. 2017. Chaetozone coro- 
na (Polychaeta, Cirratulidae) in the Bay of Biscay: a new alien species for the North-east Atlantic waters? J. Mar. Biolog. Assoc. U.K., 97: 433-445. doi:10.1017/ S0025315416000540

MUNARI, C., N. BOCCHI, P. PARRELLA, T. GRANATA, L. MORUZZI, F. MASSARA, M. DE DONATI \& M. MISTRI. 2017. The occurrence of two morphologically similar Chaetozone (Annelida: Polychaeta: Cirratulidae) species from the Italian seas: Chaetozone corona Berkeley \& Berkeley, 1941 and C. carpenteri McIntosh, 1911. Eur. Zool. J., 84:1, 541-553, doi:10.10 $80 / 24750263.2017 .1393843$

MIKAC, B. 2015. A sea of worms: polychaete checklist of the Adriatic Sea. Zootaxa, 3943: 1-172. doi:10.11646/zootaxa.3943.1.1.

OMENA, E. \& J.C. CREED. 2004. Polychaete fauna of seagrass beds (Halodule wrightii Ascher- son) along the coast of Rio de Janeiro (Southeast Brazil). Mar. Ecol., 25: 273-288. doi:10.1111/j.1439-0485.2004.00031.x

SIMBOURA, N. 1996. Marine macrobenthic polychaetes of Greece: Taxonomy, Ecology, zoogeography. PhD Thesis, University of Athens, $241 \mathrm{pp}$.

SIMBOURA, N., G.K. SAHIN, A. PANAGOULIA \& N. KATSIARAS. 2010. Four new alien species on the coasts of Greece (Eastern Mediterranean). Mediterr. Mar. Sci., 11: 341-352.

ZENETOS, A., M.E. ÇINAR, F. CROCETTA, D. GOLANI, A. ROSSO, G. SERVELlO, N. SHENKAR, X. TURON \& M. VERLAQUE. 2017. Uncertainties and validation of alien species catalogues: The Mediterranean as an example. Estuar. Coast. Shelf S., 191: 171-187. doi:10.1016/j. ecss.2017.03.031

Received: 9 May 2017

Accepted: 25 September 2017 


\title{
Novi nalazi nezavičaje vrste mnogočetinaša, Chaetozone corona (Polychaeta: Cirratulidae), u Jadranskom moru
}

\author{
Laura GROSSI, Fabio BERTASI* i Benedetta TRABUCCO
}

*Kontakt e-adresa: fabio.bertasi@gmail.com

\begin{abstract}
SAŽETAK
Nekoliko primjeraka nezavičajnog mnogočetinaša Chaetozone corona pronađeno je uzduž talijanske obale Jadranskog mora između 2006. i 2015. godine, što ukazuje na uspješnu uspostavu populacije ove vrste na tom području. Ustanovljena je morfološka varijabilnost između uzoraka iz Sjevernog i Južnog Jadrana. Metilni zeleni oblici/obrasci bojenja otkrili su daljnje manje razlike ukazujući na prisutnost dvije neznatno različite populacije.

Chaetozone corona izgleda da se ne ponaša invazivno u prirodnim uvjetima, no čini se da je oblilnija u zagađenim lučkim sedimentima, što može predstavljati glavni izvor unosa.
\end{abstract}

Ključne riječi: Chaetozone corona, nezavičajne vrste, Jadransko more, Italija 